\title{
EFFECTIVENESS OF ERYTHROPOIETIN IN CORRECTING ANEMIA IN PATIENTS OF CHRONIC KIDNEY DISEASE.
}

1. MBBS, FCPS Senior Registrar Children's Hospital \& ICH, Multan 2. MBBS, FCPS (Paediatrics Midicne) Associate Professor The Children's Hospital \& ICH Multan Pakistan.

3. MBBS, FCPS (Paediatric Medicine) Senior Registrar Paediatric Medicine Children's Hospital \& ICH, Multan

Correspondence Address:

Dr. Waqas Shakir

Senior Registrar

Children's Hospital \& ICH, Multan. waqas226@yahoo.com

Article received on: 07/05/2019

Accepted for publication: $25 / 09 / 2019$

\begin{abstract}
Waqas Shakir ${ }^{1}$, Asim Khurshid ${ }^{2}$, Muhammad Abu Talib ${ }^{3}$
\end{abstract}
ABSTRACT... Objectives: The anemia of chronic kidney disease (CKD) is commonly normocytic and normochromic. The objective of current study was to see the effectiveness of erythropoietin in correcting anemia in children with CKD. Study Design: Descriptive case series. Setting: Department of Nephrology, at The Children's hospital and the institute of child health, Multan. Period: From March 2018 to September 2018. Material \& Methods: A total of 79 children with CKD were enrolled in this study. A standard dose of erythropoietin 100 $\mathrm{IU} / \mathrm{kg}$ was given s/c biweekly and after 4 weeks patients were assessed for improvement in Hemoglobin $(\mathrm{Hb})$ level. Data were entered and analyzed using SPSS-18. Results: Of the 79 cases, $48(60.8 \%)$ were boys and $31(39.2 \%)$ girls. Mean age amongst cases was $9.92 \pm$ 2.60 years and mean weight $19.65 \pm 4.71$ Kilograms. Mean baseline hemoglobin level of our study cases was $7.88 \pm 1.09 \mathrm{gm} / \mathrm{dl}$. Mean hemoglobin level after 4 weeks of therapy with Erythropoietin was $9.22 \pm 1.04 \mathrm{gm} / \mathrm{dl}$. Majority of our study cases i.e. $56(70.88 \%)$ were having stage 1 and 2 of CKD. Correction of anemia (effectiveness) was seen in $72(91.1 \%)$ of our study cases. Conclusion: Recombinant human erythropoietin aid major improvement / correction of anemia in children with CKD. This drug can be safely used in children with CKD disease without any side effects such as hypertension.

Key words: $\quad$ Anemia, Chronic Kidney Disease, Erythropoietin, Hemoglobin.

Article Citation: Shakir W, Khurshid Asim, Talib MA. Effectiveness of erythropoietin in correcting anemia in patients of chronic kidney disease. Professional Med J 2020; 27(4):779-783. DOI: 10.29309/TPMJ/2020.27.04.3683

\section{INTRODUCTION}

Chronic kidney disease (CKD) is defined as renal injury (proteinuria) and/or glomerular filtration rate when calculated less than $60 \mathrm{ml} / \mathrm{min} / 1.73 \mathrm{~m}^{2}$ for more than 3 months. ${ }^{1}$ In pediatric population, 11 to 12 / million cases for the stage 3 to 5 CKD are estimated in Europe whereas overall prevalence is reported as approximately 55 to 60 million cases. $^{2,3}$

Most common complication and well recognized cause of morbidity in CKD is anemia. Anemia is due to decrease production of erythropoietin from failing kidneys due to tissue damage and decrease oxygen delivery to renal tissues which develops easily during the course of illness and affects almost all patients who present with some degree of reduced renal function. ${ }^{4,5}$ Anemia in CKD is normochromic normocytic. Severity of anemia is associated with extent and duration of disease. Prevalence of anemia in CKD stage 1 is

\section{$31.2 \%$ and $93.3 \%$ in CKD stage 4 and $5 . .^{6-12}$}

Erythropoietin is a hormone produced by per tubular capillaries of kidney that promotes red blood cells production (erythropoiesis) from bone marrow by increasing proliferation and maturation of erythroidprogenitors. ${ }^{13}$ Use of exogenous erythropoietin in CKD improves hemoglobin level, reduces risk of cardiovascular disease, and improves patient wellbeing and exercise tolerance. Exogenous erythropoietin is started when hemoglobin level is below normal range of age and sex. It is given subcutaneously to maintain hemoglobin between 11-12 $\mathrm{g} / \mathrm{dl}$. According to National Institute of Health and Clinical Excellence (NICE) guidelines efficacy of erythropoietin in CKD is defined as rise of $1 \mathrm{gm}$ of $\mathrm{Hb}$ in 4 weeks. ${ }^{14}$ Regular use of erythropoietin improves anemia in these patients so reducing the transfusion demand in these patients. ${ }^{15}$ Data of erythropoietin response in pediatric patients 
according to the different stages of CKD (stage $1-5)$ is not plentiful as compared to the adult patients and no study has shown the effectiveness of erythropoietin in all stages of CKD. Few studies here been done to check the response in pediatric patients. In a study conducted in the children's Hospital and the Institute of Child Health Lahore, 50 patients of pre-dialysis CKD were enrolled and given erythropoietin subcutaneously with $1001 \mathrm{lU} / \mathrm{kg} / \mathrm{biweekly.} \mathrm{Out} \mathrm{of} \mathrm{them} 92 \%$ of patients improved. But this study did not include results of stage 5 CKD patients. ${ }^{8}$

The Children's hospital and the institute of child health Multan is a tertiary level pediatric care center catering services to the children of southern Punjab. The Nephrology department manages heavy burden of patients of CKD. The aim of my study was to evaluate effectiveness of erythropoietin in raising hemoglobin level in CKD patients coming to our nephrology department. If results show effectiveness then this will guide us in better management of anemia in CKD and improving the prognosis of our patients.

\section{MATERIAL \& METHODS}

This descriptive case series was done at The Department of Nephrology, at The Children's hospital and the institute of child health, Multan, from March 2018 to September 2018.

A total of 79 cases during the study period, having CKD (either GFR less than $60 \mathrm{ml} / \mathrm{min} / 1.73 \mathrm{~m}^{2}$ or evidence of kidney injury i.e. proteinuria $>$ $30 \mathrm{mg} / \mathrm{dl}$, scarring on ultrasound, with or without decrease in GFR), ${ }^{1}$ aged $>1$ year and < 15 year, $\mathrm{Hb}<10 \mathrm{gm} / \mathrm{dl}$ and medically stable, were enrolled. Patient with iron deficiency anemia with serum ferritin $<7 \mathrm{ng} / \mathrm{ml}$, previous history of adverse reaction to erythropoietin, already taking erythropoietin or having blood transfusion in last 4 weeks, were excluded.

Before starting study, permission was taken from institutional ethical review committee. Informed consent was taken from parents/guardians after discussing all details, benefits and risks of the study. Blood sample for hemoglobin $(\mathrm{Hb})$, peripheral film and serum ferritin level were sent to our hospital's laboratory. Variables recorded for each case included name, age, gender, height, weight, surface area. Basic investigations including complete blood count, renal parameters, urinalysis, ultrasound kidney, ureter, bladder (KUB) and glomerular filtration rate were calculated by schawrtz formula and patients were categorized according to GFR (eGFR). All the patients were stabilized to minimum $\mathrm{Hb}$ level of 6 $\mathrm{g} / \mathrm{dl}$. A standard dose of erythropoietin $100 \mathrm{lU} / \mathrm{kg}$ was given s/c biweekly and after 4 weeks patients were assessed for improvement of $\mathrm{Hb}$ level. All data was entered in a pre-designed proforma. Outcome variable in term of improvement of $\mathrm{Hb}>1$ $\mathrm{gm} / \mathrm{dl}$ in 4 weeks was taken as effectiveness. ${ }^{14}$

Data was analyzed using SPSS version 18.0. Frequency and percentage were calculated for gender, stages of CKD, and effectiveness of erythropoietin. Stratification was done with respect to age, gender, base line $\mathrm{Hb}$, and stages of CKD. Post stratification chi square test has been applied. $P$ value less than or equal to 0.05 have been taken as significant.

\section{RESULTS}

Of the 79 cases, 48 (60.8\%) were boys and 31 $(39.2 \%)$ were girls. Mean age of our study cases was $9.92 \pm 2.60$ years (ranging 5 to 14 years). Study results have also indicated that majority of our cases i.e. 59 (74. $7 \%$ ) were in the range of age groups 9 to 15 years. Mean weight of our study cases was $19.65 \pm 4.71$ Kilograms (minimum weight was $12 \mathrm{Kg}$ while maximum weight was $30 \mathrm{Kg}$ ). Majority i.e. 52 (65.8\%) of our study cases had weight in the range of $10-20 \mathrm{Kg}$. Mean height of the study cases was $116.95 \pm 18.14$ $\mathrm{cm}$ (minimum height was $96 \mathrm{~cm}$ while maximum height was $149 \mathrm{~cm}$ ). Majority of our study cases i.e. $53(67.1 \%)$ had height in the range of 95 - 125 $\mathrm{cm}$. Mean baseline hemoglobin level of our study cases was $7.88 \pm 1.09 \mathrm{gm} / \mathrm{dl}$ (with minimum $\mathrm{Hb}$ level was $6.1 \mathrm{gm} / \mathrm{dl}$ while maximum $\mathrm{Hb}$ level was $9.9 \mathrm{gm} / \mathrm{dl}$ ). Mean hemoglobin level after 4 weeks of therapy with Erythropoietin was $9.22 \pm 1.04$ $\mathrm{gm} / \mathrm{dl}$ (with minimum $\mathrm{Hb}$ level was $7.4 \mathrm{gm} / \mathrm{dl}$ while maximum $\mathrm{Hb}$ level was $11.2 \mathrm{gm} / \mathrm{dl}$ ).

Majority of our study cases i.e. 56 (70.88\%) were 
having stage 1 and 2 of CKD, 16 (20.3\%) were in stage 3 of CKD, 5 (6.3\%) with stage 4 and only 2 (2.5\%) presented with stage 5 of CKD.

Correction of anemia (effectiveness) was seen in $72(91.1 \%)$ of our study cases. This effectiveness was stratified with regards to the gender $(p=$ $0.068)$, age of patients $(p=0.836)$, weight $(p=$ $0.743)$, height $(p=0.798)$, baseline Hb levels ( $p$ $=0.430)$ and stages of CKD $(p=0.001)$.

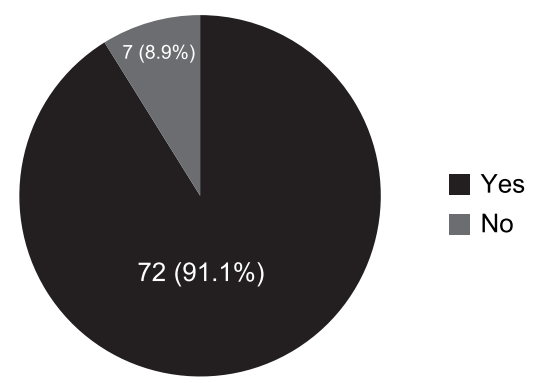

Figure-1. Effectiveness of erythropoietin $(n=79)$.

\section{DISCUSSION}

Renal anemia is a well-recognized complication of CKD with erythropoietin deficiency being the primary cause. Lower levels of glomerular filtration rate (GFR) are associated with lower levels of hemoglobin, and in adults the latter is most pronounced when the GFR falls below $60 \mathrm{~mL} /$ min per $1.73 \mathrm{~m}^{1}{ }^{1}$ This condition is associated with multiple adverse clinical consequences and its management is a core component of nephrology care. Increased morbidity and mortality, increased risk of cardiovascular disease and decreased quality of life have been associated with anemia of CKD in children. Our study included 79 children with CKD, 48 (60.8\%) were male and 31 (39.2\%) were female. Our study findings are similar to that of Akhtar $\mathrm{N}$ et $\mathrm{al}^{5}$ who have also reported that anemia being more prevalent in male patients rather than female patients (62\% male versus $38 \%$ females) in their study.

\begin{tabular}{|c|c|c|c|}
\hline \multirow[b]{2}{*}{ Study Variables } & \multicolumn{2}{|c|}{ Effectiveness } & \multirow[b]{2}{*}{ P-Value } \\
\hline & $\begin{array}{c}\text { Yes } \\
(n=72)\end{array}$ & $\begin{array}{c}\text { No } \\
(n=07)\end{array}$ & \\
\hline Male & $46(63.9 \%)$ & $02(28.6 \%)$ & \multirow{2}{*}{0.068} \\
\hline Female & $26(36.1 \%)$ & $05(71.4 \%)$ & \\
\hline \multicolumn{4}{|l|}{ Age Group (years) } \\
\hline $1-8$ & $18(25.0 \%)$ & $2(28.6 \%)$ & \multirow{2}{*}{0.836} \\
\hline $9-15$ & $54(75.0 \%)$ & $5(71.4 \%)$ & \\
\hline \multicolumn{4}{|l|}{ Weight (kg) } \\
\hline $10-20$ & 47 (65.3\%) & $5(71.4 \%)$ & 0.743 \\
\hline $126-150$ & $24(33.3 \%)$ & $2(28.6 \%)$ & 0.798 \\
\hline \multicolumn{4}{|l|}{ Stages of CKD } \\
\hline Stage 1 & $23(31.9 \%)$ & 00 & \multirow{5}{*}{0.001} \\
\hline Stage 2 & $33(45.8 \%)$ & 00 & \\
\hline Stage 3 & $16(22.2 \%)$ & 00 & \\
\hline Stage 4 & 00 & $05(71.4 \%)$ & \\
\hline Stage 5 & 00 & $02(28.6 \%)$ & \\
\hline \multicolumn{4}{|c|}{ Baseline Hemoglobin (gm/dl) } \\
\hline
\end{tabular}


However our findings are different from that of Jungers et $\mathrm{al}^{16}$ who reported significantly more prevalent anemia in female patients than male patients. Another trial reported $65 \%$ male patients with anemia, these findings are in consistence with our findings. ${ }^{17}$

Mean age of our study cases was $9.92 \pm 2.60$ years (ranging 5 to 14 years). Study results have also indicated that majority of our cases i.e. 59 $(74.7 \%)$ were in the range of age groups 9 to 15 years. Akhtar $\mathrm{N}$ et $\mathrm{al}^{8}$ reported 7.68 years mean age which is a bit low than ours.

Mean weight of our study cases was $19.65 \pm$ 4.71 Kilograms (minimum weight was $12 \mathrm{Kg}$ while maximum weight was $30 \mathrm{Kg}$ ). Majority i.e. $52(65.8 \%)$ of our study cases had weight in the range of $10-20 \mathrm{Kg}$. Akhtar $\mathrm{N}$ et al ${ }^{8}$ reported 21.65 $\mathrm{Kg}$ mean weight of their study participants, similar to our study.

Mean baseline hemoglobin level of our study cases was $7.88 \pm 1.09 \mathrm{gm} / \mathrm{dl}$ (with minimum $\mathrm{Hb}$ level was $6.1 \mathrm{gm} / \mathrm{dl}$ while maximum $\mathrm{Hb}$ level was $9.9 \mathrm{gm} / \mathrm{dl}$ ). Akhtar $\mathrm{N}$ et $\mathrm{al}^{8}$ reported $8.20 \pm 1.28$ $\mathrm{gm} / \mathrm{dl}$, which is close to our findings. Jungers et al reported $8.8 \pm 0.7 \mathrm{~g} / \mathrm{dl}$ baseline $\mathrm{Hb}$ levels. While mean $\mathrm{Hb}$ level was $9.5 \pm 0.6 \mathrm{gm} / \mathrm{dl}$ in another trial. ${ }^{17}$

Mean hemoglobin level after 4 weeks of therapy with Erythropoietin was $9.22 \pm 1.04 \mathrm{gm} / \mathrm{dl}$, with minimum $\mathrm{Hb}$ level was $7.4 \mathrm{gm} / \mathrm{dl}$ while maximum $\mathrm{Hb}$ level was $11.2 \mathrm{gm} / \mathrm{dl}$. Akhtar $\mathrm{N}$ et al reported $10.94 \pm 1.04$, which is close to our study findings. Jungers $\mathrm{P}$ et $\mathrm{al}^{16}$ reported a bit higher mean levels for of $\mathrm{Hb}$ i.e. $11.3 \pm 0.9 \mathrm{gm} / \mathrm{dl}$. Mean $\mathrm{Hb}$ levels were $10.8 \pm 1 \mathrm{gm} / \mathrm{dl}$ in a large population trial of 403 patients. ${ }^{17}$

Majority of our study cases i.e. 56 (70.88\%) were having stage 1 and 2 of CKD, 16 (20.3\%) were in stage 3 of CKD, 5 (6.3\%) with stage 4 and only $2(2.5 \%)$ presented with stage 5 of CKD. Our findings are in contrast to that of Akhtar et $\mathrm{al}^{5}$ while are in compliance with that Jungers $P$ et al. ${ }^{16}$ Correction of anemia (effectiveness) was seen in $72(91.1 \%)$ of our study cases. Akhtar et $\mathrm{al}^{8}$ reported $92 \%$ correction of anemia in such cases. In our findings, erythropoietin was found to be safe in children with CKD without any side effects such as hypertension.

\section{CONCLUSION}

Recombinant human erythropoietin has significant impact on the improvement/ correction of anemia in children with CKD. This drug has potential to improve the quality of life of these patients and lower the burden on health authorities in terms of hospital stays and delayed start of dialysis.

Copyright $(25$ Sep, 2019.

\section{REFERENCES}

1. KDIGO 2012 clinical practice guideline for the evaluation and management of chronic kidney disease. Kidney Int Suppl 2013; 3:1.

2. Becherucci F, Roperto RM, Materassi M, Romagnani P. Chronic kidney disease in children. Clinical Kidney Journal 2016; 9(4):583-91.

3. Ardissino G, Daccò V, Testa S, Bonaudo R, Claris-Appiani $A$, Taioli $E$, et al. Epidemiology of chronic renal failure in children: Data from the Ital Kid project. Pediatrics 2003; 111 (4 Pt 1):e382.

4. KDOQI: National Kidney Foundation. KDOQI clinical practice guidelines and clinical practice recommendations for anemia in chronic kidney disease. Am J Kidney Dis 2006; 47 (Suppl 3):S11-S145.

5. 72. Atkinson MA, Furth SL. Anemia in children with chronic kidney disease. Nat Rev Nephrol 2011; 7:63541.

6. Reddy-keth SR, Singh AK. Hemoglobin target in chronic kidney disease. Pediatric Nephrol. 2009; 24(3):431-4.

7. Rahman H, Jahan S, Begum A, Muinuddin G, Hossain $M M$. Use of recombinant human erythropoietin in renal anemia in children. BSMMU. 2009; 2(1):50-3.

8. Akhtar N, Tahir M, Kiran S. Recombinant human erhthropoietin therapy in predialysis patient in chronic kidney disease. Nephrology Review. 2010; 2(1):43-6.

9. Azhir A, Nasiri J, Ghasari A, Prevalence and severity of anemia in pediatric hemodialysis patient; A single center study. IRAN J PED. 2007; 17(01):28-35. 
10. Kidney disease outcome quality initiative. Clinical practice guidelines for chronic kidney disease: Evaluation, classification and stratification. Am J Kidney Dis 2002; 39[suppl 2]:S1-S246.

11. Abdu A, Arogundade F, Adamu B, Dutse Al, Sanusi A, Sani MU, et al. Anaemia and its response to treatment with recombinant human erythropoietin in chronic kidney disease patients. West Afr J Med. 2009; 28(5):295-9.

12. Harambat J, van Stralen KJ, Kim JJ, Tizard EJ. Epidemiology of chronic kidney disease in children. Pediatr Nephrol. 2012; 27(3):363-73.

13. Warady BA, Silverstein DM. Management of anemia with erythropoietic-stimulating agents in children with chronic kidney disease. Pediatr Nephrol 2014; 29:1493-1505.
14. National collaborating centre for chronic conditions, royal college of physicians. Guideline on anaemia management in chronic kidney disease. 2015. National Institute for Clinical Excellence. Available on http://www.nice.org.uk/guidance/NG8/evidence. Accessed 15 June 2017.

15. Boehm M. Early erythropoietin therapy is associated with improved growth in children with chronic kidney disease. Pediatr Nephrol 2007; 22: 1189-1193.

16. Jungers P, Choukroun G, Oualim Z, Robino C, Nguyen $A$, Man N. Beneficial influence of recombinant human Erythropoietin on the rate of progression of chronic renal failure in pre-dialysis patients. Nephrol Dial Transplant. 2001; 16:307-12.

17. Jungers P, Robino C, Choukroun G, Khoa TN, Massy ZA, Jungers $P$. Incidence of anemia, and use of epoietin in pre-dialysis patients: A prospective study in $\mathbf{4 0 3}$ patients. Nephrol Dial Transplant. 2002; 17:1621.

\begin{tabular}{|c|c|c|c|}
\hline \multicolumn{3}{|c|}{ AUTHORSHIP AND CONTRIBUTION DECLARATION } \\
\hline Sr. \# & \multicolumn{1}{|c|}{ Author(s) Full Name } & \multicolumn{1}{|c|}{ Contribution to the paper } & Author(s) Signature \\
\hline 1 & Waqas Shakir & $\begin{array}{l}\text { Data collection, Drafting, } \\
\text { Discussion. } \\
\text { Ideae, Methodology, Literature } \\
\text { Review, Data analysis, Proof } \\
\text { reading. } \\
\text { Data collection, Methodology, } \\
\text { Literature Review, Discussion. }\end{array}$ \\
\hline 3 & Asim Khurshid & Muhammad Abu Talib & fij! \\
\hline
\end{tabular}

